OPEN ACCESS

Edited by:

Georgia Fousteri,

San Raffaele Hospital (IRCCS), Italy

Reviewed by:

Guido Ferrari,

Duke University, United States

Karin Schilbach,

Universität Tübingen, Germany

${ }^{*}$ Correspondence:

Peter P. Lee

plee@coh.org

Constantinos Petrovas

petrovasc@mail.nih.gov

Specialty section:

This article was submitted to

$T$ Cell Biology,

a section of the journal

Frontiers in Immunology

Received: 10 May 2018 Accepted: 07 September 2018 Published: 27 September 2018

Citation:

Poultsidi A, Dimopoulos Y, He T-F, Chavakis T, Saloustros E, Lee PP and

Petrovas C (2018) Lymph Node Cellular Dynamics in Cancer and HIV: What Can We Learn for the Follicular

CD4 (Tfh) Cells?

Front. Immunol. 9:2233

doi: 10.3389/fimmu.2018.02233

\section{Lymph Node Cellular Dynamics in Cancer and HIV: What Can We Learn for the Follicular CD4 (Tfh) Cells?}

\author{
Antigoni Poultsidi ${ }^{1}$, Yiannis Dimopoulos ${ }^{2}$, Ting-Fang He ${ }^{3}$, Triantafyllos Chavakis ${ }^{4}$, \\ Emmanouil Saloustros ${ }^{5}$, Peter P. Lee ${ }^{3 *}$ and Constantinos Petrovas ${ }^{2 *}$
}

${ }^{1}$ Department of Surgery, Medical School, University of Thessaly, Larissa, Greece, ${ }^{2}$ Tissue Analysis Core, Immunology Laboratory, Vaccine Research Center, NIAID, NIH, Bethesda, MD, United States, ${ }^{3}$ Department of Immuno-Oncology, Beckman Research Institute, City of Hope Comprehensive Cancer Center, Duarte, CA, United States, ${ }^{4}$ Institute of Clinical Chemistry and Laboratory Medicine, Technische Universität Dresden, Dresden, Germany, ${ }^{5}$ Department of Internal Medicine, Medical School, University of Thessaly, Larissa, Greece

Lymph nodes (LNs) are central in the generation of adaptive immune responses. Follicular helper CD4 T (Tfh) cells, a highly differentiated CD4 population, provide critical help for the development of antigen-specific B cell responses within the germinal center. Throughout the past decade, numerous studies have revealed the important role of Tfh cells in Human Immunodeficiency Virus (HIV) pathogenesis as well as in the development of neutralizing antibodies post-infection and post-vaccination. It has also been established that tumors influence various immune cell subsets not only in their proximity, but also in draining lymph nodes. The role of local or tumor associated lymph node Tfh cells in disease progression is emerging. Comparative studies of Tfh cells in chronic infections and cancer could therefore provide novel information with regards to their differentiation plasticity and to the mechanisms regulating their development.

Keywords: cancer, HIV, Tfh cells, lymph nodes, follicles

\section{INTRODUCTION}

Given the important role the lymphatic system has in combating foreign pathogens, changes in Lymph Node (LN) architecture/cellularity have been recognized in a variety of infectious diseases. In Human Immunodeficiency Virus (HIV) infection, LNs play a central role for disease pathogenesis. Early studies revealed the covert infection of CD4 T cells in the LN and its role in the depletion of these cells throughout disease progress $(1,2)$. From a prognostic point of view, the degree of follicular structure damage has been used for classification of disease progress $(3,4)$. Current vaccine strategies targeting the humoral arm of the immune system have revealed the need for a comprehensive understanding of follicular dynamics. Given the role of $\mathrm{T}$ follicular helper (Tfh) cells as an HIV reservoir (5) and as critical "helpers" in the development of antibodies (6), understanding their biology is of great interest.

Besides infectious diseases, LNs are involved in various forms of neoplasia, either as metastasis or as primary disease sites (i.e., lymphomas). It is of critical importance to distinguish between infectious etiologies of lymphadenopathy vs. neoplastic causes (7). In non-hematopoietic neoplastic disease, LNs are involved in disease progression (a) as part of the regional disease, contributing to local morbid phenomena when infiltrated by the tumor, (b) as metastatic disease per se$(\mathrm{N}$ status in the Tumor Node Metastasis staging system)-affecting the treatment/management of patients, and (c) as a mediator for propagating further distant metastasis. Although LN 
involvement has major prognostic implications for the patient and is thus incorporated in the staging strategies of neoplasms (8), the clinical management of the lymphatic system draining a malignancy is an area of ongoing research and trends are shifting accordingly. For example, in breast cancer patients attention has been drawn to the Sentinel Lymph Node (SLN) (9), which is defined as the first LN or group of LNs that interstitial fluid and cells from the tumor microenvironment pass through on their route to the venous circulation via lymphatic vessels (10-12). Despite the different etiology and specific pathways/molecular factors operating selectively in cancer or infectious diseases, the comparative analysis of $\mathrm{LN}$ immunedynamics could provide important information regarding the development and maintenance of Th cells.

\section{LYMPH NODES: ORGANIZATION, TFH CELLS}

LNs provide the site of initiation of adaptive immune responses and are strategically placed along lymphatic vessels (13). Antigen presenting cells (APCs) initiate immune responses via interactions with $\mathrm{T}$ and $\mathrm{B}$ cells that gain access to specific regions of the LN (14). Functionally, the LNs can be separated into lobules (13). The structural backbone of the lobule is comprised of Fibroblastic Reticular Cells (FRCs) and their fibers, which support the parenchyma, provide routes for the migration of lymphocytes, and facilitate the interaction between lymphocytes and APCs (4). The inter-follicular regions of the cortex and the paracortex are mainly populated by $\mathrm{T}$ cells, which gain access to the parenchyma by migrating through high endothelial venules (HEVs), following the CCR7/CCL19, CCL21 axis (4). These cells interact with dendritic cells (DCs) that have reached the LN via the afferent lymphatic vessels and HEVs (4). Primary follicles (located in the cortex) contain mainly naïve B cells, whereas secondary follicles are recognized by the formation of a germinal center (GC) (13). GCs, the antibody production factory of the body, are populated by antigen stimulated B cells, follicular dendritic cells (FDCs), Tfh cells, and macrophages- among other cell types $(15,16)$. FDCs can present antigens and stimulatory signals to GC B and T cells, as well as produce CXCL-13, the ligand for CXCR5 (17), while tingible body macrophages are capable of phagocytizing dying cells (13).

Tfh cells provide critical signals for the activation, isotype switching, affinity maturation, and differentiation of B cells into memory B cells and plasma cells via surface bound receptors (i.e., PD-1, ICOS, CD40) $(18,19)$ and secreted factors like IL-21 and IL-4 $(20,21)$, that support the GC responses by regulating the differntiation of both Tfh and B cells through the activation of STAT signaling pathways (21-25). The spatial organization of Tfhs cells is regulated, at least, by (i) chemokine gradients (i.e., CXCL-13 and CXCL-10/IP-10, a chemokine produced by macrophages and acting on CXCR3) enabling their trafficking toward GC $(17,26)$. and (ii) function of signaling pathways mediating their retention within the follicular/GC areas. GC homing is accomplished via downregulation of CCR7 and upregulation of CXCR5- a process mediated by Bcl-6, a critical transcription factor for Tfh cell differentiation $(27,28)$. Once inside the GC, S1PR1 family receptors aid in Tfh cell retention in GCs- this is accomplished by downregulation of S1PR1 and upregulation of S1PR2 (29-31). Dynamic positioning inside the GC is influenced by the local production of factors, one of which is CXCL-12/SDF-1 that acts on CXCR4 $(32,33)$. The unique PD- $1{ }^{\text {hi }}$ CXCR $5{ }^{\text {hi }}$ phenotype has been widely used for the identification of Tfh cells $(34,35)$. In line with this, imaging studies have shown the highly skewed localization of PD- 1 hi CD4 T cells within the GC areas (GC-Tfh cells) (35-37). High expression per cell (judged by Mean Fluoresense Intensity-MFI) of other surface receptors (like ICOS and TIGIT), is selectively found on the vast majority of GC-Tfh cells $(35,37,38)$. The differential expression of surface receptors like CD150 and CD57 can further delineate GC-Tfh subpopulations (35, 37, 39). For example, Tfh cells expressing lower levels of CD150 (SLAM) secrete higher levels of IL-4 and are thought to be more differentiated than Th cells expressing higher levels of CD150 $(37,39)$. The presence of PD- $1^{\text {dim }}$ CXCR5 ${ }^{\text {hi }}$ (non-GC) Tfh (34), the differential expression of CXCR3 (Th1-like Tfh cells) (40, 41), or Tfh master regulators like Bcl-6 (5, 28, 35), further adds to the heterogeneity of the Tfh pool. We should emphasize, though, that different follicular CD4 T cell subsets are presumably exposed to different local signals within the follicle. Delineation of these signals, as well as the connection between phenotype and function of Tfh cell subsets, is an important step toward the comprehensive understanding of Tfh cell biology and their role in human diseases.

A separate group of CD4 T cells located in the follicle/GC- and particularly the T-B area border (42)- are T follicular regulatory (Tfr) cells (43), which possibly originate from thymic T regulatory (Treg) cells, after adaption of their gene expression profile to include -apart from FoxP3- factors and receptors expressed in Tfh cells, such as Bcl-6 and CXCR5 (38, 44, 45). A mutual regulation between Tfh and GC B cells through the function of receptor/ligand axes (such as CD40/CD40L, ICOS-ICOSL) has been proposed (46-48). In a similar manner, Tfr cells can suppress GC reactivity (43) either by altering such mutual regulation- a process mediated in part by CTLA-4 (49)- or by directly affecting B or Tfh cells $(43,50)$. Although they represent a small minority of follicular CD4 T cells, the presence of Tfr cells aids in limiting the GC response to prevent uncontrolled $\mathrm{B}$ cell proliferation and the consequences thereof, such as the production of antibodies that recognize "self" antigens $(37,44)$.

\section{LYMPH NODES IN NEOPLASMS}

\section{The Concept of SLNs}

From an immunological perspective, SLNs are the site where tumor antigen loaded APCs encounter naïve T and B cells, leading to the generation of immune responses against neoplasms (51-53). A relatively smaller distance from the primary tumor site presumably increases the possibility for the SLN to be affected by the tumor than downstream draining LNs (DLNs) are, potentially leading to the variable immune responses observed in DLNs depending on the distance from the primary tumor (54). Factors which modulate these responses may tip the balance 
from control to tolerance/spread of the neoplasm (51-53). Most research has focused on SLNs in the context of melanoma and breast cancer patients, but knowledge is expanding about SLNs in other types of neoplasms -such as genitourinary, pulmonary, and gastrointestinal tumors (11). However, accurate identification of SLNs can be very challenging (55). Rerouting of lymphatic flow or the presence of tumor cells in the subcapsular sinus may affect the ability to detect the SLN with the help of dyes (55, 56). Lymphangiogenesis and alterations of lymph flow dynamics induced by the tumor may also alter lymphatic drainage (55). Therefore, a false negative SLN (up to $9.8 \%$ in breast cancer) could result in under-staging and mistreating patients $(57,58)$.

\section{Structural Alterations of SLNs Induced by Tumors}

Tumors can affect structural components in the SLNs and DLNs even before metastasis to these sites has occurred, creating an environment fostering tumor cell invasion to the SLN (5961). Major structural SLN changes have been described, related to (a) increased lymphatic drainage from the tumor to the LNs (55), which can induce biophysical remodeling/changes of the LN matrix (62) and potentially lead to the activation of signaling pathways [i.e., transforming growth factor (TGF)$\beta$ pathway] associated with tumor spreading/induction of immune suppression in the LNs, in a similar fashion to what has been observed in primary tumor sites (63), (b) increased lymphangiogenesis and angiogenesis induced by vascular endothelial growth factors (VEGFs) originating from the tumor environment, which can ultimately contribute to the spreading of tumor cells to the SLN and beyond (55, 60, 6466), and (c) a "flatter" morphology of the endothelial cells of the HEVs, which can potentially lead to impaired access of naïve $\mathrm{T}$ cells to the LN parenchyma (53). Overall, these structural changes in the lymphatics and the vasculature can set the stage for future metastasis of cancer cells to SLNs (Figure 1).

\section{Non-follicular Immune Dynamics in SLNs}

Apart from structural changes, modulations of immune cell subsets have also been observed to precede actual metastasis of tumor cells to SLNs. Several studies suggest a compromised capacity to induce a "favorable" Th-1 response against the tumor due to (i) decreased DC density and clustering in paracortical LN regions (67-70) and (ii) compromised DC function (60, 70-72). Conversely, other studies have advocated increased presence of activated DCs in SLNs, prior to the appearance of metastatic cells (73-75). However, transition to a mature DC phenotype and Th1 cytokine response was noted after metastasis of breast tumor cells to the SLN, possibly reflecting antigenic stimulation against these cells (72) (Figure 1). Emerging studies have investigated the role of LN NK cells (76) and monocytes/macrophages in anti-tumor immunity $(77,78)$ and their targeting for adjuvant immunotherapies that could improve treatment of patients with metastatic cancer. Regarding adaptive immunity, alterations in cell types with prognostic implications (68) have been observed in SLNs and DLNs. Reduced numbers of CD4 and CD8 T cells $(60,64,68)$ with an immunosuppressed profile (79) was found in SLNs, a profile associated with accumulation of FoxP3+
Treg CD4 cells in LNs harboring metastases (80-83) and worse prognosis/more widespread nodal disease in melanoma, breast, and gastric cancer (82-85). Various cytokines (GM-CSF, IL-2) are being investigated as a way to reverse this immune suppression and assist in the immune system's effort to combat the neoplastic cells (53).

\section{Follicular Dynamics in SLNs and Tertiary Lymphoid Structures (TLSs)}

In contrast to extrafollicular cell dynamics, much less is known about follicular/B cell dynamics in the context of neoplastic disease. In SLNs, B cells- via the secretion of VEGF-Acould induce lymphangiogenesis and angiogenesis $(61,86,87)$, potentially promoting the spread of tumors via lymphatics (55). However, an extended lymphatic network can lead to increased recruitment of DCs from the periphery to the LN (86), which could ultimately benefit the development of anti-tumor adaptive immunity. A trend toward improved 5-year survival was noted in melanoma patients, whose SLNs demonstrated follicular hyperplasia/GC accumulation (88). Besides their prognostic value for disease-free survival in breast cancer patients (89), SLN B cells is the source of affinity matured B cell clones that produced anti-tumor immunoglobulins detected in the blood (90). Investigation of such antibodies could potentially lead to the recognition of tumor antigens recognized by the immune system, which can subsequently be targeted in the context of immunotherapies (90). Furthermore, these findings imply that development of tumor-specific Tfh cells could be a critical factor for an effector response to a tumor. The progressive differentiation of Tfh cells within the follicular area, associated with differential localization and an orchestrated production of IL-21 and IL-4, provide critical signals for the isotype switching and differentiation of GC B cells by modulating transcription factors like Bcl-6 and Blimp-1 (21, 24, 91). In a mouse tumor model, accumulation of Tfh cells was noted in DLNs, along with a concomitant increase in IL-4 produced by these cells (92). On the other hand, recent studies have shown a beneficial role of IL-21 in cancer immunotherapy strategies $(93,94)$, possibly by modulating CD8 T cell response (95-97). Therefore, Tfh cells could potentially support antitumor immunity in ways extending past the help they provide to B cells.

The role of B cell infiltration in primary tumors is not clear (98, 99), with studies showing both a negative (100, $101)$ or a positive (102-105) effect on the antitumor immune responses. However, B cells contribute to the formation of tertiary lymphoid structures (TLSs) - defined as accumulations of lymphocytes in proximity to the primary tumor-which are associated with better prognosis (99) (Figure 1). Similar to B cells, an increased presence of Tfh cells in the primary tumor site has been associated with better clinical outcomes in breast (106) and non-small cell lung carcinoma (107). High expression of molecules like CXCL-13 and IL-21 $(106,108)$ by TLS associated Tfh cells contributes to the formation/organization of TLSs in the primary breast tumor and potentially contribute to the immune systems' reaction (109). Presumably, TLSs facilitate the in situ production and secretion of anti-tumor antibodies that 


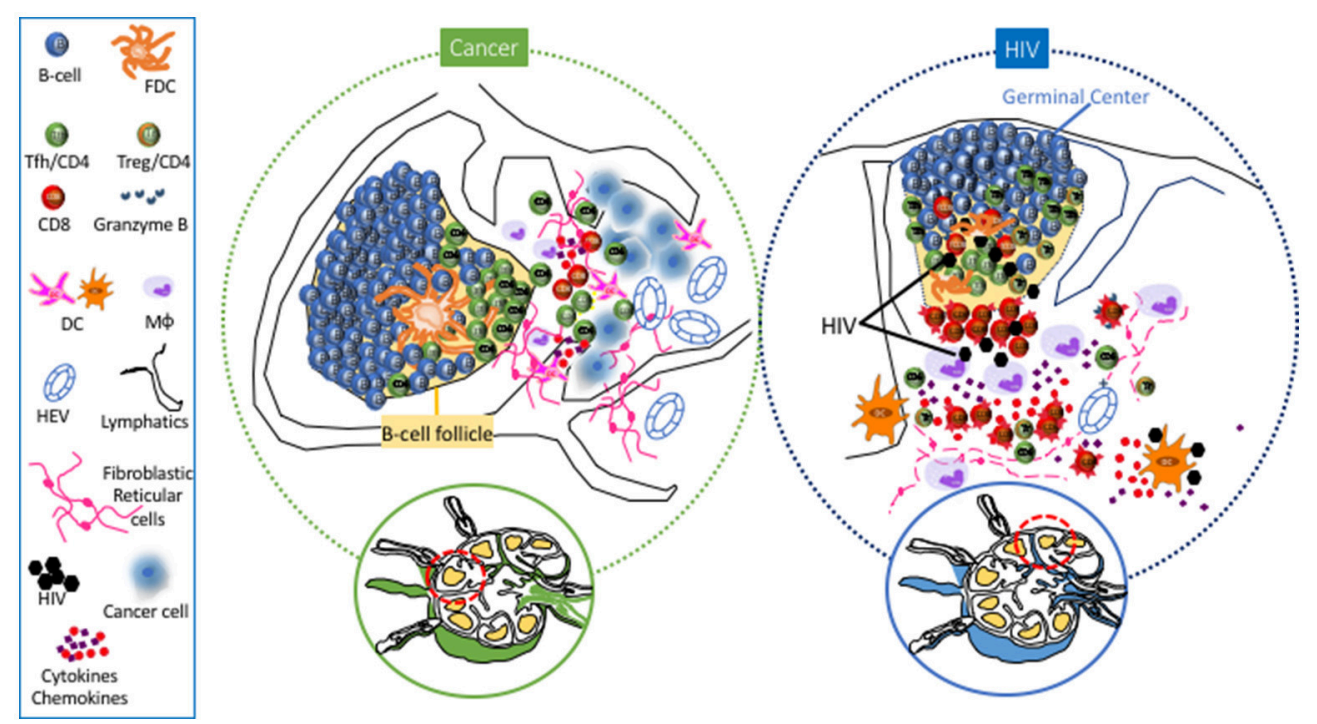

FIGURE 1 | Main Lymph Node cell dynamics in cancer (left) and HIV (right). Cancer causes lymphangiogenesis and vasculature reorganization in SLNs. Metastasis is associated with accumulation of DCs and rercuitment of moncytes/macrophages and NK cells. Follicular hyperplasia associated with the development of Tfh cells has also been observed in SLNs and particularly in TLSs. Chronic HIV/SIV infection is characterized by extensive loss of FRC and naive CD4 T cells, accumulation of monocytes/macrophages, particularly in the area surrounding the follicle, as well as accumulaiton of effector CD8 T cells in the extrafollicular area (T cell zone). Within the follicle, accumulation of Tfh cells is associated with loss of their polarized positioning in the light zone, loss of FDC network and accumulation of follicular Treg CD4 T cells (Tfr).

could represent a mechanism to maximize the efficiency of adaptive immunity against tumors (99). A variety of regulatory cell subsets have the ability to influence Tfh cell function. In breast cancer, LN Treg cells can promote malignancy through a TGF $\beta$-1 mediated upregulation of the oncogenic receptor IL17rb (110). A coevolution of Treg cells and CXCL-13 ${ }^{\text {hi }}$ Tfh cells in the TLSs was found, with the ratio between these two populations being a critical factor for tumor control by benefiting the development of an anti-tumor humoral response (109). Furthermore, the presence of myeloid-derived suppressor cells within the LN could potentially be a negative regulator for Tfh cells $(111,112)$, adding to the complexity of the regulation of these cells. Characterization of relevant cytokine producers and their spatial positioning within anatomically separated LN areas would be highly informative in understanding their potential role in regulating Tfh cell dynamics in SLN and TLSs.

Several reports have been focused on the characterization of circulating CXCR5 $5^{\text {hi }}$ CD4 $\mathrm{T}$ (cTfh) cell subsets as a counterpart of the LN bona fide Tfh cells $(113,114)$. The lineage origin of cTfh cells and their direct association to LN Tfh cells is not clear (115, 116). Lower cTfh cells in the blood of hepatocellular carcinoma patients were associated with worse prognosis (117), while a higher frequency of "Th-1" CXCR 3 hi cTfh cells was negatively associated with survival in gastric cancer (118). In breast cancer, a higher frequency of "exhausted" Tim- 3 hi cTfh cells associated with higher expression of PD-1 per cell base was found interestingly, in vitro blocking of Tim-3 increased the production of IL-21 and CXCL-13 by peripheral blood mononuclear cells (119). Future investigation of cTfhs in cancers of different etiology could provide important information regarding their use as a biomarker, as well as their relationship to LN or TLS Tfh cells.

\section{FOLLICULAR IMMUNE DYNAMICS: LESSONS FROM HIV/SIV (SIMIAN IMMUNODEFICIENCY VIRUS)}

\section{Structural Alterations}

HIV infection leads to dramatic and progressive changes of LN architecture, especially evident during the chronic phase of infection (4). In reality, the degree of tissue damage has been used for the staging of disease (120). A major contributor to this damage is the extensive deposition of collagen (fibrosis) in the extrafollicular area (121), a process facilitated by increased levels of secreted TGF- $\beta 1$ from accumulated Treg cells (122, 123) and the activation of spatially associated fibroblasts (124, 125). Fibrosis leads to a vicious circle of naïve $\mathrm{T}$ cell pool and FRC network depletion $(126,127)$ - a network that provides the scaffold for cell migration (128) and vital signals for the recruitment (CCR7) $(129,130)$ and survival (IL-7) $(130,131)$ of naive T cells (Figure 1). LN damage is associated with the persistent immune activation and tissue inflammation found in HIV/SIV (4). Despite the partial normalization of immunological parameters- such as CD4 counts, immune activation, and suppressed viremia- LN structure abnormalities persist in combination antiretroviral therapy (cART)-treated individuals (132-134), presumably affecting the development and function of LN relevant T cells -such as Tfh cells- in the context of new infections or vaccination (36). 


\section{Non-follicular Immune Dynamics}

Besides tissue architecture, HIV/SIV infection has a major impact on the cellular dynamics within the extrafollicular areas. Monocytes/macrophages that express low levels of CD4 and other HIV coreceptors (135) can contribute to HIV/SIV pathogenesis by (i) supporting the viral reservoir, particularly in advanced disease or immunocompromised states $(136,137)$, and (ii) secreting inflammatory mediators like IL-6 and IL10 (138), which play an important role in the development of GC responses (139). The accumulation of monocytic-lineage and plasmacytoid dendritic cells (pDCs) in LNs during acute SIV infection (140-143) is followed by their impaired function (leading to decreased production of cytokines like IFN-a and IL-12, which in vitro support $\mathrm{T}$ cell proliferation) during the chronic phase of infection (144-146). Despite the loss of both pDCs and myeloid DCs (mDCs) from lymphoid tissues and blood in chronic infection, LN-derived mDCs retain their functionality, especially the induction of Treg cells- an important regulator of Tfh cell function and GC reactivity $(147,148)$. Chronic HIV/SIV is characterized by the relative loss of $\mathrm{LN}$ CD4 cells- mainly attributed to loss of naïve CD4T cells (39, 126, 149)- accompanied by an increased frequency of effector CD8 T cells (149) (Figure 1). Besides the direct killing of infected CD4 T cells, the cellular and molecular mechanisms regulating the LN T cell dynamics in HIV/SIV are not well understood. Structure damage, immune activation, inflammatory signals, and altered tissue chemokine gradients could all play an important role in this process. Recent studies have shown that chronic HIV/SIV infection is associated with sequestration of monocytes/macrophages around the follicular areas (150). Their possible role in LN CD8 T cell dynamics is supported by their (i) correlation with LN CD8 T cell in chronic SIV (149), (ii) spatial proximity to accumulated CD8 T cells in LN areas $(149,150)$, and (iii) potential to change local chemokine gradients through the secretion of chemokines like CXCL-9 and CXCL-10 (IP10) $(151,152)$, ligands for the CXCR3 receptor that is broadly expressed on LN CD8 T cells (149). Such altered chemokine gradients could contribute to LN T cell dynamics by modulating their (i) recruitment from the circulation $(153,154)$ and (ii) intra lymph node trafficking (26).

\section{Follicular Dynamics}

Understanding the follicular/GC- and particularly Tfh cellimmune dynamics in HIV/Simian Immunodeficiency Virus (SIV) infection is of great importance for (i) the identification of molecules/pathways associated with the development of broadly neutralizing antibodies that could inform the design of novel vaccine strategies targeting relevant GC cell populations and (ii) understanding the establishment and maintenance of a major viral reservoir (5), even in cART treated donors (155). To this end, the non-human primate (NHP) SIV model has provide invaluable information regarding the Tfh cell dynamics during infection. A relatively delayed development of Tfh cells during acute SIV has been described in peripheral LNs (39). Interestingly, different kinetics between spleen and $\mathrm{LN}$ associated Tfh cells has been found, indicating a differential regulation of Tfh cells in different lymphoid organs $(156,157)$. Chronic
HIV/SIV infection is associated with an altered (a) frequency (39), (b) function and signaling $(39,156)$, (c) molecular profile $(39,158)$, and (d) localization/distribution within the follicular areas (159) of Tfh cells (Figure 1). The dynamics of LN Tfh cells- associated with follicular hyperplasia in the LNs and hypergammaglobulinemia in the plasma (39, 160-162)- have been linked to progression to AIDS $(162,163)$, as well as to immune activation and associated cytokines-such as IL-6 and IFN- $\gamma(19,39,161)$. The dependence of Th cells on immune activation and tissue inflammation is further supported by their downregulation in cART individuals $(5,160)$ and by the lack of accumulation of Tfh cells in LNs from infected African Green Monkeys (AGMs) (149), a natural host of the virus with no signs of immune activation (164). Apart from the altered frequency, SIV infection has a significant impact on the molecular signature of Tfh cells- characterized by upregulation of IFN- $\gamma$ and TGF$\beta$ related genes (39)- indicating an increased response of $\mathrm{Tfh}$ cells to relevant stimuli and a role of TGF- $\beta$ as regulator of Tfh cell dysfunction in chronic infection. The combination of (i) an increased expression of CXCL-13 in Tfh cells (39), (ii) a favorable phosphorylation of STAT3 (a positive regulator of Tfh cells $(39,158)$ ) over STAT1 (39), and (iii) an increased expression of the IL-6/IL-6R axis found in chronic SIV (39) provides a molecular basis for the accumulation of Tfh cells in chronic HIV/SIV. Besides Bcl-6, SIV infection induces the expression of c-Maf (157), a master regulator of Tfh cells (139). Interestingly, a higher expression of T-bet (a Th-1 regulator) was found selectively in LN Tfh cells (157), in line with the accumulation of Th1-like Tfh cells in chronic SIV (165). The relative presence of such Tfh populations could have a significant effect on HIV/SIV pathogenesis (165).

Despite the accumulation of Tfh cells $(5,39)$ and GC B cells $(39,156)$, the majority of HIV-infected individuals do not develop broadly neutralizing antibodies against HIV (166), pointing to a perturbation of the Tfh-B cell interaction within the GC (167). Increased frequencies of Gag-specific compared to Env-specific Tfh cells found in chronic HIV $(5,39)$ could reflect a preferential development of Gag-specific Tfh cells or increased turnover of Env-specific Tfh cells. Application of cutting-edge technologies like single cell deep sequencing would be highly informative to this end. Analysis of Simian-Human immunodeficiency virus (SHIV) infected NHPs revealed that besides the frequency, the quality (judged by the expression of IL-21 vs. IFN- $\gamma$ ) of Env-specific Tfh responses was strongly associated with the development of broadly neutralizing antibodies in those animals (168). The increased expression of IL-21 found in HIV-specific Tfh cells $(5,160)$, could be counterbalanced by a reduced expression of IL- 4 by Tfh cells (39), indicating that the development of broadly neutralizing analysis requires the orchestrated expression and activity of relevant cells and soluble mediators.

Other mechanisms that could contribute to the impaired functionality of Tfh cells in chronic HIV/SIV include (i) the high expression of PD-L1 on germinal center B cells, interacting with the highly expressed PD-1 on Tfh cells (52), (ii) the relative accumulation of potential suppressor Tfr cells (169) and (iii) the presence of follicular regulatory CD8 T cells (170). Besides 
the frequency and quality of relevant cells, preservation of the follicular structure is a critical determinant for the development of GC responses in HIV infection- which is characterized by the loss of the Follicular Dendritic Cells (FDC) network and factors secreted by this network, such as CXCl-13 (36). Recent imaging studies revealed that preservation of FDC was associated with maintenance of Tfh cells and preservation of their function in HIV infection, manifested by the response of infected individuals to vaccination (36) and possibly with their distribution within the GC (Figure 2).

HIV/SIV infection affects the dynamics of other LN cells, including CD8 T cells. An increased frequency of follicular CD8 T cells $(149,150,165)$ - even within intact follicles (149)has been observed, implying that infection counteracts local "firewalls" that naturally keep CD8 T cells outside the follicular area. Although the naturally induced HIV-specific cytotoxic CD8 lymphocytes are relatively excluded from the GC area (171), the increased overall presence of follicular CD8 $\mathrm{T}$ cells provides an opportunity for novel CD8-based immunotherapies, i.e., the use of bispecific antibodies to redirect these cells to kill HIV-infected cells $(149,172)$. Immune activation and tissue inflammation are important factors for the dynamics of both follicular CD4 and CD8 T cells in chronic infection (149). The excessive immune activation, however, possibly leads to a generalized, non-cognate driven expansion of these cell populations. One could hypothesize that these dynamics could potentially affect the function of virus-specific Tfh responses, i.e., through the aberrant production of Tfh-cytokines.

\section{CONCLUDING REMARKS, FUTURE DIRECTIONS}

Comparative studies using Tfh cells from diseases with different etiologies represent one way to better understand the molecular and cellular basis for their generation and maintenance. Specifically, such studies between HIV and cancer could inform for:

1. The mechanisms of $T f h$ development/maintenance in the settings of a chronic disease. Besides the relative frequency and spatial positioning, HIV/SIV infection changes the molecular profile of Th cells too (39). Is this profile of chronically in vivo stimulated Tfh cells unique for HIV/SIV or there is a core, preserved molecular signature during Tfh cell development under different stimuli like cancer neoantigens? Does the etiology/type of cancer have an impact on this profile? Relevant studies will provide critical information about the plasticity of the Tfh cell differentiation program.

2. The role of tissue inflammation in the development of human Tfh cell responses. Despite the expected differences between HIV and cancer-including, among others, the (a) nature of antigenic stimulation (viral proteins compared to neoantigens), (b) magnitude/type of tissue architectural changes, (c) presence of virus within the follicle and its ability to infect Tfh cells per se in HIV infectioninflammation plays an important role in the pathogenesis of both diseases (172-174). Comparative investigation of LNs from HIV infected individuals and cancer patients could inform for the presence, spatial distribution and possible role of specific pro-inflammatory cellular/molecular mediators for the recruitment of T cell to LNs and their trafficking between LN compartments. General, non-cognate driven activation of LN CD 4 T cells could differ between cancer and a chronic viral infection like HIV, with a presumably differential impact in the generation of Tfh cell responses. Therefore, the development of methodologies allowing for the detection of antigen-specific Tfh cells, especially at tissue level, is of great importance.

3. The impact of tissue structure alterations on Tfh cell dynamics and the and local interplay between adaptive immunity and Tfh cells. Tissue changes like vasculature reorganization and extracellular matrix organization are less studied in HIV compared to cancer LNs. On the other hand, common tissue structure alterations like fibrosis could contribute to Tfh cell dynamics by affecting the dynamics of innate and adaptive immune cells in the extrafollicular areas (167). HIV/SIV is characterized by the accumulation of LN and particularly follicular CD8 T cells $(148,149)$. The regulation of these dynamics as well as the role of fCD8 T cells in GC B cell responses is not well understood. Conversely, the role of cytokines, like IL-21 produced by Tfh cells too, as regulators of LN CD8 T cells is not clear either. Understanding the interplay between LN CD8 T cells and Tfh cells is of
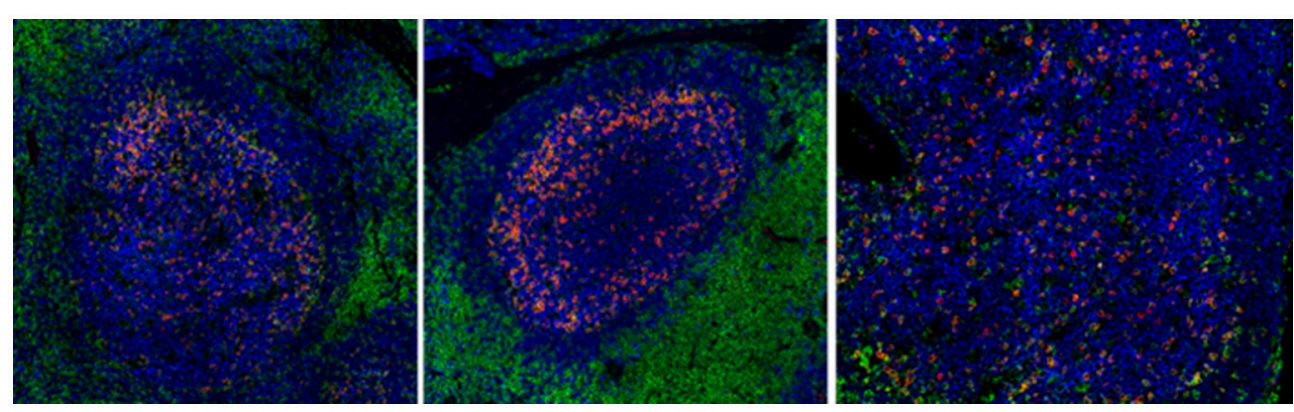

FIGURE 2 | Chronic HIV infection is associated with disturbed follicular organization. Reactive follicles from a healthy axillary (left), a breast cancer SLN (middle) and a HIV viremic axillary LN (right). The CD20 (blue), CD4 (green), and PD-1 (red) markers are shown. 
great importance for $\mathrm{LN}$ immune responses both in HIV and cancer, particularly within TLSs, where sequestration of effector CD8 T cells in proximity to the tumor site could have an impact on disease progression.

4. The "anatomical compartmentalization" of Tfh cell responses. Are all Tfh cells across the human body the same? Recent studies have shown a differential regulation of Tfh cells between LNs and spleen in SIV infection (156). Is this the case for LN Tfh cells from different anatomical sites too? How that could affect the role of adaptive immunity responses developed in LN in the progression of cancer with different topology?

5. The assessment of human Tfh cell quality. Comparison of Tfh cells between HIV donors with broadly neutralizing antibodies and cancer donors with anti-tumor B cell response correlating with good prognosis could help define the spatial organization, the functional characteristics, and molecular signature of an "effective" Tfh cell response.

Given the limited, if any, access to LN tissues, especially from different time points throughout the course of disease, the discovery of circulating biomarkers recapitulating the germinal center reactivity is of great importance. Investigation of molecules like CXCL13 $(37,173)$ or cTfh cells (113) represents one direction in the hunt for biomarkers i.e., for monitoring the efficacy of vaccination protocols (175). Are cancers of different etiology associated with a particular phenotype/subset of cTfh cells? How do these cells compare to cTfh subsets found in HIV?

An in depth understanding of the Tfh cell development is a prerequisite for the designing of novel in vivo interventions aimed at boosting their function and developing effective B cell responses, particularly in HIV. Many questions are still open; how the prime/boost vaccination scheme affects the quality and breath of immunogen-specific Tfh responses? Combining optimal structure-based designed immunogens with new generation adjuvants or interventions targeting specific molecules/pathways involved in the generation of high quality Tfh cells could lead to more efficient vaccine strategies. On the other hand, any therapeutic intervention has to take in

\section{REFERENCES}

1. Pantaleo G, Graziosi C, Demarest JF, Butini L, Montroni M, Fox $\mathrm{CH}$, et al. HIV infection is active and progressive in lymphoid tissue during the clinically latent stage of disease. Nature (1993) 362:355-8. doi: $10.1038 / 362355 \mathrm{a} 0$

2. Embretson J, Zupancic M, Ribas JL, Burke A, Racz P, Tenner-Racz K, et al. Massive covert infection of helper T lymphocytes and macrophages by HIV during the incubation period of AIDS. Nature (1993) 362:359-62. doi: $10.1038 / 362359 \mathrm{a} 0$

3. Baroni CD, Uccini S. Lymph nodes in HIV-positive drug abusers with persistent generalized lymphadenopathy: histology, immunohistochemistry, and pathogenetic correlations. Prog AIDS Pathol. (1990) 2:33-50.

4. Estes JD. Pathobiology of HIV/SIV-associated changes in secondary lymphoid tissues. Immunol Rev. (2013) 254:65-77. doi: 10.1111/imr. 12070

5. Perreau M, Savoye AL, De Crignis E, Corpataux JM, Cubas R, Haddad EK, et al. Follicular helper T cells serve as the major CD4 T cell compartment for consideration the best short and long-term oncological outcome, as well as survivors' quality of life. Surgical interventions may be associated with morbidity/mortality. For example, axillary LN dissection in the context of breast cancer might result in an increased incidence of lifetime lymphedema (up to $21 \%$ ), decreased arm mobility, and arm paresthesia (174). However, recent clinical trials are challenging the need for axillary surgery for tumors up to $2 \mathrm{~cm}(175,176)$. New therapeutic schemes are urgently needed. The success of cancer immunotherapy in melanoma, lung cancer, renal cell carcinoma and other solid tumors has placed the power of $\mathrm{T}$ cell immunity into the armamentarium of cancer therapeutics. Similar immune therapies for patients with breast cancer are beginning to come to fruition, with most promising the use of PD-1 (e.g., pembrolizumab) and PD-L1 (e.g., avelumab) monoclonal antibodies $(177,178)$. However, the toxicity and cost of immunotherapies has revealed the need for predictive biomarkers. Potential biomarkers should be evaluated in the primary tumor, in the metastases, or in circulation. Given their role in breast cancer, the search for novel biomarkers at a $\mathrm{LN}$ and follicular level could be of great support for the decision of relevant surgical procedures.

\section{AUTHOR CONTRIBUTIONS}

AP, YD, TF-H, and ES wrote the manuscript. TC, PL, and CP conceived the idea and participated in the writing and editing the manuscript.

\section{ACKNOWLEDGMENTS}

Authors would like to thank the personnel of Tissue Analysis Core at VRC, NIAID for helpful discussions and suggestions and Dr E. Moysi for help with the cartoon figure. This research was supported by the Intramural Research Program of the Vaccine Research Center, NIAID, National Institutes of Health and CAVD grant (\#OP1032325) from the Bill and Melinda Gates Foundation.
HIV-1 infection, replication, and production. J Exp Med. (2013) 210:143-56. doi: $10.1084 /$ jem.20121932

6. Breitfeld D, Ohl L, Kremmer E, Ellwart J, Sallusto F, Lipp M, et al. Follicular B helper T cells express CXC chemokine receptor 5, localize to B cell follicles, and support immunoglobulin production. J Exp Med. (2000) 192:1545-52. doi: 10.1084/jem.192.11.1545

7. Slack GW. The pathology of reactive lymphadenopathies: a discussion of common reactive patterns and their malignant mimics. Arch Pathol Lab Med. (2016) 140:881-92. doi: 10.5858/arpa.2015-0482-SA

8. Edge SB, Compton CC. The American Joint Committee on Cancer: the 7 th edition of the AJCC cancer staging manual and the future of TNM. Ann Surg Oncol. (2010) 17:1471-4. doi: 10.1245/s10434-010-0985-4

9. Giuliano AE, Kirgan DM, Guenther JM, Morton DL. Lymphatic mapping and sentinel lymphadenectomy for breast cancer. Ann Surg. (1994) 220:3918; discussion 8-401. doi: 10.1097/00000658-199409000-00015

10. Krag DN, Weaver DL. Pathological and molecular assessment of sentinel lymph nodes in solid tumors. Semin Oncol. (2002) 29:274-9. doi: $10.1053 /$ sonc. 2002.32894 
11. Cochran AJ, Roberts AA, Saida T. The place of lymphatic mapping and sentinel node biopsy in oncology. Int J Clin Oncol. (2003) 8:139-50. doi: 10.1007/s10147-003-0333-9

12. Uren RF, Thompson JF, Howman-Giles R. Sentinel lymph node biopsy in patients with melanoma and breast cancer. Intern Med J. (2001) 31:547-53. doi: 10.1046/j.1445-5994.2001.01282.x

13. Willard-Mack CL. Normal structure, function, and histology of lymph nodes. Toxicol Pathol. (2006) 34:409-24. doi: 10.1080/01926230600867727

14. Zeng M, Haase AT, Schacker TW. Lymphoid tissue structure and HIV1 infection: life or death for T cells. Trends Immunol. (2012) 33:306-14. doi: 10.1016/j.it.2012.04.002

15. Mesin L, Ersching J, Victora GD. Germinal center B cell dynamics. Immunity (2016) 45:471-82. doi: 10.1016/j.immuni.2016.09.001

16. Victora GD, Schwickert TA, Fooksman DR, Kamphorst AO, MeyerHermann M, Dustin ML, et al. Germinal center dynamics revealed by multiphoton microscopy with a photoactivatable fluorescent reporter. Cell (2010) 143:592-605. doi: 10.1016/j.cell.2010.10.032

17. Ansel KM, Ngo VN, Hyman PL, Luther SA, Forster R, Sedgwick JD, et al. A chemokine-driven positive feedback loop organizes lymphoid follicles. Nature (2000) 406:309-14. doi: 10.1038/35018581

18. Crotty S. T follicular helper cell differentiation, function, and roles in disease. Immunity (2014) 41:529-42. doi: 10.1016/j.immuni.2014.10.004

19. Kim CH, Lim HW, Kim JR, Rott L, Hillsamer P, Butcher EC. Unique gene expression program of human germinal center T helper cells. Blood (2004) 104:1952-60. doi: 10.1182/blood-2004-03-1206

20. Shulman Z, Gitlin AD, Weinstein JS, Lainez B, Esplugues E, Flavell RA, et al. Dynamic signaling by $\mathrm{T}$ follicular helper cells during germinal center B cell selection. Science (2014) 345:1058-62. doi: 10.1126/science.1257861

21. Weinstein JS, Herman EI, Lainez B, Licona-Limon P, Esplugues E, Flavell $\mathrm{R}$, et al. TFH cells progressively differentiate to regulate the germinal center response. Nat Immunol. (2016) 17:1197-205. doi: 10.1038/ni.3554

22. Wu Y, van Besouw NM, Shi Y, Hoogduijn MJ, Wang L, Baan CC. The biological effects of IL-21 signaling on B-cell-mediated responses in organ transplantation. Front Immunol. (2016) 7:319. doi: 10.3389/fimmu.2016.00319

23. Nurieva RI, Chung Y, Hwang D, Yang XO, Kang HS, Ma L, et al. Generation of $\mathrm{T}$ follicular helper cells is mediated by interleukin-21 but independent of T helper 1, 2, or 17 cell lineages. Immunity (2008) 29:138-49. doi: 10.1016/j.immuni.2008.05.009

24. Chevrier S, Kratina T, Emslie D, Tarlinton DM, Corcoran LM. IL4 and IL21 cooperate to induce the high Bcl6 protein level required for germinal center formation. Immunol Cell Biol. (2017) 95:925-32. doi: 10.1038/icb.2017.71

25. Berglund LJ, Avery DT, Ma CS, Moens L, Deenick EK, Bustamante J, et al. IL-21 signalling via STAT3 primes human naive B cells to respond to IL-2 to enhance their differentiation into plasmablasts. Blood (2013) 122:3940-50. doi: 10.1182/blood-2013-06-506865

26. Groom JR, Richmond J, Murooka TT, Sorensen EW, Sung JH, Bankert K, et al. CXCR3 chemokine receptor-ligand interactions in the lymph node optimize CD4+ T helper 1 cell differentiation. Immunity (2012) 37:1091103. doi: 10.1016/j.immuni.2012.08.016

27. Ballesteros-Tato A, Randall TD. Priming of $\mathrm{T}$ follicular helper cells by dendritic cells. Immunol Cell Biol. (2014) 92:22-7. doi: 10.1038/icb.2013.62

28. Kroenke MA, Eto D, Locci M, Cho M, Davidson T, Haddad EK, et al. Bcl6 and Maf cooperate to instruct human follicular helper CD4 T cell differentiation. J Immunol. (2012) 188:3734-44. doi: 10.4049/jimmunol.1103246

29. Bankovich AJ, Shiow LR, Cyster JG. CD69 suppresses sphingosine 1phosophate receptor-1 (S1P1) function through interaction with membrane helix 4. J Biol Chem. (2010) 285:22328-37. doi: 10.1074/jbc.M110.123299

30. Moriyama S, Takahashi N, Green JA, Hori S, Kubo M, Cyster JG, et al. Sphingosine-1-phosphate receptor 2 is critical for follicular helper $\mathrm{T}$ cell retention in germinal centers. J Exp Med. (2014) 211:1297-305. doi: 10.1084/jem.20131666

31. Blankenbach KV, Schwalm S, Pfeilschifter J, Meyer Zu Heringdorf D. Sphingosine-1-phosphate receptor-2 antagonists: therapeutic potential and potential risks. Front Pharmacol. (2016) 7:167. doi: 10.3389/fphar.2016.00167

32. Estes JD, Thacker TC, Hampton DL, Kell SA, Keele BF, Palenske EA, et al. Follicular dendritic cell regulation of CXCR4-mediated germinal center CD4 T cell migration. J Immunol. (2004) 173:6169-78. doi: 10.4049/jimmunol.173.10.6169

33. Elsner RA, Ernst DN, Baumgarth N. Single and coexpression of CXCR4 and CXCR5 identifies CD4T helper cells in distinct lymph node niches during influenza virus infection. J Virol. (2012) 86:7146-57. doi: 10.1128/JVI.06904-11

34. Kohler SL, Pham MN, Folkvord JM, Arends T, Miller SM, Miles B, et al. Germinal center $\mathrm{T}$ follicular helper cells are highly permissive to HIV1 and alter their phenotype during virus replication. J Immunol. (2016) 196:2711-22. doi: 10.4049/jimmunol.1502174

35. Alshekaili J, Chand R, Lee CE, Corley S, Kwong K, Papa I, et al. STAT3 regulates cytotoxicity of human $\mathrm{CD} 57+\mathrm{CD} 4+\mathrm{T}$ cells in blood and lymphoid follicles. Sci Rep. (2018) 8:3529. doi: 10.1038/s41598-018-21389-8

36. Moysi E, Pallikkuth S, De Armas LR, Gonzalez LE, Ambrozak D, George V, et al. Altered immune cell follicular dynamics in HIV infection following influenza vaccination. J Clin Invest. (2018) 128:3171-85. doi: 10.1172/JCI99884

37. Amodio D, Cotugno N, Macchiarulo G, Rocca S, Dimopoulos Y, Castrucci MR, et al. Quantitative multiplexed imaging analysis reveals a strong association between immunogen-specific B cell responses and tonsillar germinal center immune dynamics in children after influenza vaccination. J Immunol. (2018) 200:538-50. doi: 10.4049/jimmunol.17 01312

38. Wu H, Chen Y, Liu H, Xu LL, Teuscher P, Wang S, et al. Follicular regulatory $\mathrm{T}$ cells repress cytokine production by follicular helper $\mathrm{T}$ cells and optimize IgG responses in mice. Eur J Immunol. (2016) 46:1152-61. doi: 10.1002/eji.201546094

39. Petrovas C, Yamamoto T, Gerner MY, Boswell KL, Wloka K, Smith EC, et al. CD4 T follicular helper cell dynamics during SIV infection. J Clin Invest. (2012) 122:3281-94. doi: 10.1172/JCI63039

40. Bentebibel SE, Khurana S, Schmitt N, Kurup P, Mueller C, Obermoser G, et al. ICOS(+)PD-1(+)CXCR3(+) T follicular helper cells contribute to the generation of high-avidity antibodies following influenza vaccination. Sci Rep. (2016) 6:26494. doi: 10.1038/srep26494

41. Velu V, Mylvaganam GH, Gangadhara S, Hong JJ, Iyer SS, Gumber S, et al. Induction of Th1-biased T follicular helper (Tfh) cells in lymphoid tissues during chronic simian immunodeficiency virus infection defines functionally distinct germinal center Tfh cells. J Immunol. (2016) 197:183242. doi: 10.4049/jimmunol.1600143

42. Sayin I, Radtke AJ, Vella LA, Jin W, Wherry EJ, Buggert M, et al. Spatial distribution and function of $\mathrm{T}$ follicular regulatory cells in human lymph nodes. J Exp Med. (2018) 215:1531-42. doi: 10.1084/jem.201 71940

43. Linterman MA, Pierson W, Lee SK, Kallies A, Kawamoto S, Rayner TF, et al. Foxp3 + follicular regulatory $\mathrm{T}$ cells control the germinal center response. Nat Med. (2011) 17:975-82. doi: 10.1038/nm.2425

44. Vaeth M, Muller G, Stauss D, Dietz L, Klein-Hessling S, Serfling E, et al. Follicular regulatory $\mathrm{T}$ cells control humoral autoimmunity via NFAT2-regulated CXCR5 expression. J Exp Med. (2014) 211:545-61. doi: $10.1084 /$ jem.20130604

45. Chung Y, Tanaka S, Chu F, Nurieva RI, Martinez GJ, Rawal S, et al. Follicular regulatory $\mathrm{T}$ cells expressing Foxp3 and Bcl-6 suppress germinal center reactions. Nat Med. (2011) 17:983-8. doi: 10.1038/nm.2426

46. Weinstein JS, Bertino SA, Hernandez SG, Poholek AC, Teplitzky TB, Nowyhed HN, et al. B cells in T follicular helper cell development and function: separable roles in delivery of ICOS ligand and antigen. J Immunol. (2014) 192:3166-79. doi: 10.4049/jimmunol.1302617

47. Baumjohann D, Preite S, Reboldi A, Ronchi F, Ansel KM, Lanzavecchia $A$, et al. Persistent antigen and germinal center B cells sustain $T$ follicular helper cell responses and phenotype. Immunity (2013) 38:596-605. doi: 10.1016/j.immuni.2012.11.020

48. Liu D, Xu H, Shih C, Wan Z, Ma X, Ma W, et al. T-B-cell entanglement and ICOSL-driven feed-forward regulation of germinal centre reaction. Nature (2015) 517:214-8. doi: 10.1038/nature13803

49. Sage PT, Paterson AM, Lovitch SB, Sharpe AH. The coinhibitory receptor CTLA-4 controls $\mathrm{B}$ cell responses by modulating $\mathrm{T}$ follicular helper, $\mathrm{T}$ follicular regulatory, and T regulatory cells. Immunity (2014) 41:1026-39. doi: 10.1016/j.immuni.2014.12.005 
50. Sage PT, Ron-Harel N, Juneja VR, Sen DR, Maleri S, Sungnak W, et al. Suppression by TFR cells leads to durable and selective inhibition of B cell effector function. Nat Immunol. (2016) 17:1436-46. doi: 10.1038/ni.3578

51. Kim R, Emi M, Tanabe K, Arihiro K. Immunobiology of the sentinel lymph node and its potential role for antitumour immunity. Lancet Oncol. (2006) 7:1006-16. doi: 10.1016/S1470-2045(06)70975-5

52. Takeuchi H, Kitajima M, Kitagawa Y. Sentinel lymph node as a target of molecular diagnosis of lymphatic micrometastasis and local immunoresponse to malignant cells. Cancer Sci. (2008) 99:441-50. doi: 10.1111/j.1349-7006.2007.00672.x

53. Cochran AJ, Huang RR, Lee J, Itakura E, Leong SP, Essner R. Tumourinduced immune modulation of sentinel lymph nodes. Nat Rev Immunol. (2006) 6:659-70. doi: 10.1038/nri1919

54. Cochran AJ, Pihl E, Wen DR, Hoon DS, Korn EL. Zoned immune suppression of lymph nodes draining malignant melanoma: histologic and immunohistologic studies. J Natl Cancer Inst. (1987) 78:399-405.

55. Karaman S, Detmar M. Mechanisms of lymphatic metastasis. J Clin Invest. (2014) 124:922-8. doi: 10.1172/JCI71606

56. Clough KB, Nasr R, Nos C, Vieira M, Inguenault C, Poulet B. New anatomical classification of the axilla with implications for sentinel node biopsy. $\mathrm{Br} J$ Surg. (2010) 97:1659-65. doi: 10.1002/bjs.7217

57. Krag DN, Anderson SJ, Julian TB, Brown AM, Harlow SP, Costantino JP, et al. Sentinel-lymph-node resection compared with conventional axillary-lymphnode dissection in clinically node-negative patients with breast cancer: overall survival findings from the NSABP B-32 randomised phase 3 trial. Lancet Oncol. (2010) 11:927-33. doi: 10.1016/S1470-2045(10)70207-2

58. Krag DN, Anderson SJ, Julian TB, Brown AM, Harlow SP, Ashikaga T, et al. Technical outcomes of sentinel-lymph-node resection and conventional axillary-lymph-node dissection in patients with clinically node-negative breast cancer: results from the NSABP B-32 randomised phase III trial. Lancet Oncol. (2007) 8:881-8. doi: 10.1016/S1470-2045(07)70278-4

59. Zuckerman NS, Yu H, Simons DL, Bhattacharya N, Carcamo-Cavazos V, Yan N, et al. Altered local and systemic immune profiles underlie lymph node metastasis in breast cancer patients. Int J Cancer (2013) 132:2537-47. doi: $10.1002 /$ ijc. 27933

60. Mansfield AS, Holtan SG, Grotz TE, Allred JB, Jakub JW, Erickson LA, et al. Regional immunity in melanoma: immunosuppressive changes precede nodal metastasis. Mod Pathol. (2011) 24:487-94. doi: 10.1038/modpathol.2010.227

61. Harrell MI, Iritani BM, Ruddell A. Tumor-induced sentinel lymph node lymphangiogenesis and increased lymph flow precede melanoma metastasis. Am J Pathol. (2007) 170:774-86. doi: 10.2353/ajpath.2007.060761

62. Rohner NA, McClain J, Tuell SL, Warner A, Smith B, Yun Y, et al. Lymph node biophysical remodeling is associated with melanoma lymphatic drainage. FASEB J. (2015) 29:4512-22. doi: 10.1096/fj.15-274761

63. Swartz MA, Lund AW. Lymphatic and interstitial flow in the tumour microenvironment: linking mechanobiology with immunity. Nat Rev Cancer (2012) 12:210-9. doi: 10.1038/nrc3186

64. Grotz TE, Jakub JW, Mansfield AS, Goldenstein R, Enninga EA, Nevala WK, et al. Evidence of Th2 polarization of the sentinel lymph node (SLN) in melanoma. Oncoimmunology (2015) 4:e1026504. doi: 10.1080/2162402X.2015.1026504

65. Balsat C, Blacher S, Herfs M, Van de Velde M, Signolle N, Sauthier P, et al. A specific immune and lymphatic profile characterizes the pre-metastatic state of the sentinel lymph node in patients with early cervical cancer. Oncoimmunology (2017) 6:e1265718. doi: 10.1080/2162402X.2016.1265718

66. Hirakawa S, Brown LF, Kodama S, Paavonen K, Alitalo K, Detmar M. VEGF-C-induced lymphangiogenesis in sentinel lymph nodes promotes tumor metastasis to distant sites. Blood (2007) 109:1010-7. doi: 10.1182/blood-2006-05-021758

67. van den Hout M, Koster BD, Sluijter BJR, Molenkamp BG, van de Ven R, van den Eertwegh AJM, et al. Melanoma sequentially suppresses different DC subsets in the sentinel lymph node, affecting disease spread and recurrence. Cancer Immunol Res. (2017) 5:969-77. doi: 10.1158/2326-6066.CIR-17-0110

68. Kohrt HE, Nouri N, Nowels K, Johnson D, Holmes S, Lee PP. Profile of immune cells in axillary lymph nodes predicts disease-free survival in breast cancer. PLoS Med. (2005) 2:e284. doi: 10.1371/journal.pmed.00 20284
69. Cochran AJ, Morton DL, Stern S, Lana AM, Essner R, Wen DR. Sentinel lymph nodes show profound downregulation of antigen-presenting cells of the paracortex: implications for tumor biology and treatment. Mod Pathol. (2001) 14:604-8. doi: 10.1038/modpathol.3880358

70. Chang AY, Bhattacharya N, Mu J, Setiadi AF, Carcamo-Cavazos V, Lee GH, et al. Spatial organization of dendritic cells within tumor draining lymph nodes impacts clinical outcome in breast cancer patients. J Transl Med. (2013) 11:242. doi: 10.1186/1479-5876-11-242

71. Kara PP, Ayhan A, Caner B, Gultekin M, Ugur O, Bozkurt MF, et al. Analysis of dendritic cells in sentinel lymph nodes of patients with endometrial and patients with cervical cancers. Int J Gynecol Cancer (2009) 19:1239-43. doi: 10.1111/IGC.0b013e3181b3e616

72. Matsuura K, Yamaguchi Y, Ueno H, Osaki A, Arihiro K, Toge T. Maturation of dendritic cells and T-cell responses in sentinel lymph nodes from patients with breast carcinoma. Cancer (2006) 106:1227-36. doi: 10.1002/cncr.21729

73. Poindexter NJ, Sahin A, Hunt KK, Grimm EA. Analysis of dendritic cells in tumor-free and tumor-containing sentinel lymph nodes from patients with breast cancer. Breast Cancer Res. (2004) 6:R408-15. doi: 10.1186/bcr808

74. Sakakura K, Chikamatsu K, Sakurai T, Takahashi K, Murata T, Oriuchi $\mathrm{N}$, et al. Infiltration of dendritic cells and NK cells into the sentinel lymph node in oral cavity cancer. Oral Oncol. (2005) 41:89-96. doi: 10.1016/j.oraloncology.2004.07.004

75. Bembenek A, Li J, Loddenkemper C, Kemmner W, Stein H, Wernecke KD, et al. Presence of mature DC-Lamp+ dendritic cells in sentinel and nonsentinel lymph nodes of breast cancer patients. Eur J Surg Oncol. (2008) 34:514-8. doi: 10.1016/j.ejso.2007.05.013

76. Messaoudene M, Fregni G, Fourmentraux-Neves E, Chanal J, Maubec E, Mazouz-Dorval S, et al. Mature cytotoxic CD56(bright)/CD16(+) natural killer cells can infiltrate lymph nodes adjacent to metastatic melanoma. Cancer Res. (2014) 74:81-92. doi: 10.1158/0008-5472.CAN-13-1303

77. Shiota T, Miyasato Y, Ohnishi K, Yamamoto-Ibusuki M, Yamamoto Y, Iwase $\mathrm{H}$, et al. The clinical significance of CD169-positive lymph node macrophage in patients with breast cancer. PLoS ONE (2016) 11:e0166680. doi: 10.1371/journal.pone.0166680

78. Cella M, Jarrossay D, Facchetti F, Alebardi O, Nakajima H, Lanzavecchia A, et al. Plasmacytoid monocytes migrate to inflamed lymph nodes and produce large amounts of type I interferon. Nat Med. (1999) 5:919-23. doi: $10.1038 / 11360$

79. Schule JM, Bergkvist L, Hakansson L, Gustafsson B, Hakansson A. CD28 expression in sentinel node biopsies from breast cancer patients in comparison with CD3-zeta chain expression. J Transl Med. (2004) 2:45. doi: 10.1186/1479-5876-2-45

80. Viguier M, Lemaitre F, Verola O, Cho MS, Gorochov G, Dubertret $\mathrm{L}$, et al. Foxp3 expressing $\mathrm{CD} 4+\mathrm{CD} 25$ (high) regulatory $\mathrm{T}$ cells are overrepresented in human metastatic melanoma lymph nodes and inhibit the function of infiltrating $\mathrm{T}$ cells. J Immunol. (2004) 173:1444-53. doi: 10.4049/jimmunol.173.2.1444

81. Martin F, Ladoire S, Mignot G, Apetoh L, Ghiringhelli F. Human FOXP3 and cancer. Oncogene (2010) 29:4121-9. doi: 10.1038/onc.2010.174

82. Mohos A, Sebestyen T, Liszkay G, Plotar V, Horvath S, Gaudi I, et al. Immune cell profile of sentinel lymph nodes in patients with malignant melanoma - FOXP3 + cell density in cases with positive sentinel node status is associated with unfavorable clinical outcome. J Transl Med. (2013) 11:43. doi: 10.1186/1479-5876-11-43

83. Mansfield AS, Heikkila PS, Vaara AT, von Smitten KA, Vakkila JM, Leidenius MH. Simultaneous Foxp3 and IDO expression is associated with sentinel lymph node metastases in breast cancer. BMC Cancer (2009) 9:231. doi: 10.1186/1471-2407-9-231

84. Nakamura R, Sakakibara M, Nagashima T, Sangai T, Arai M, Fujimori T, et al. Accumulation of regulatory $\mathrm{T}$ cells in sentinel lymph nodes is a prognostic predictor in patients with node-negative breast cancer. Eur J Cancer (2009) 45:2123-31. doi: 10.1016/j.ejca.2009.03.024

85. Lee HE, Park DJ, Kim WH, Kim HH, Lee HS. High FOXP3+ regulatory T-cell density in the sentinel lymph node is associated with downstream non-sentinel lymph-node metastasis in gastric cancer. Br J Cancer (2011) 105:413-9. doi: 10.1038/bjc.2011.248

86. Angeli V, Ginhoux F, Llodra J, Quemeneur L, Frenette PS, Skobe $\mathrm{M}$, et al. B cell-driven lymphangiogenesis in inflamed lymph nodes 
enhances dendritic cell mobilization. Immunity (2006) 24:203-15. doi: 10.1016/j.immuni.2006.01.003

87. Ruddell A, Mezquita P, Brandvold KA, Farr A, Iritani BM. B lymphocytespecific c-Myc expression stimulates early and functional expansion of the vasculature and lymphatics during lymphomagenesis. Am J Pathol. (2003) 163:2233-45. doi: 10.1016/S0002-9440(10)63581-X

88. Abbott J, Buckley M, Taylor LA, Xu G, Karakousis G, Czerniecki BJ, et al. Histological immune response patterns in sentinel lymph nodes involved by metastatic melanoma and prognostic significance. J Cutan Pathol. (2018) 45:377-86. doi: 10.1111/cup.13127

89. Blenman KR, He T-F, Frankel PH, Ruel NH, Schwartz EJ, Krag DN, et al. Sentinel lymph node B cells can predict disease-free survival in breast cancer patients. npj Breast Cancer. (2018) 4:28. doi: 10.1038/s41523-018-0081-7

90. McDaniel JR, Pero SC, Voss WN, Shukla GS, Sun Y, Schaetzle S, et al. Identification of tumor-reactive B cells and systemic IgG in breast cancer based on clonal frequency in the sentinel lymph node. Cancer Immunol Immunother. (2018) 67:729-38. doi: 10.1007/s00262-018-2123-2

91. Belanger S, Crotty S. Dances with cytokines, featuring TFH cells, IL-21, IL-4 and B cells. Nat Immunol. (2016) 17:1135-6. doi: 10.1038/ni.3561

92. Shirota H, Klinman DM, Ito SE, Ito H, Kubo M, Ishioka C. IL4 from T follicular helper cells downregulates antitumor immunity. Cancer Immunol Res. (2017) 5:61-71. doi: 10.1158/2326-6066.CIR-16-0113

93. Lewis KE, Selby MJ, Masters G, Valle J, Dito G, Curtis WR, et al. Interleukin21 combined with PD-1 or CTLA-4 blockade enhances antitumor immunity in mouse tumor models. Oncoimmunology (2017) 7:e1377873. doi: 10.1080/2162402X.2017.1377873

94. Chen C, Liu X, Ren Y. Interleukin 21 treatment in a murine model as a novel potential cytokine immunotherapy for colon cancer. Adv Clin Exp Med. (2018) 27:583-9. doi: 10.17219/acem/68703

95. Xin G, Schauder DM, Lainez B, Weinstein JS, Dai Z, Chen Y, et al. A Critical role of IL-21-Induced BATF in sustaining CD8-T-cell-mediated chronic viral control. Cell Rep. (2015) 13:1118-24. doi: 10.1016/j.celrep.2015.09.069

96. Frohlich A, Kisielow J, Schmitz I, Freigang S, Shamshiev AT, Weber J, et al. IL-21R on T cells is critical for sustained functionality and control of chronic viral infection. Science (2009) 324:1576-80. doi: 10.1126/science.1172815

97. Raeber ME, Zurbuchen Y, Impellizzieri D, Boyman O. The role of cytokines in T-cell memory in health and disease. Immunol Rev. (2018) 283:176-93. doi: 10.1111/imr.12644

98. Guy TV, Terry AM, Bolton HA, Hancock DG, Shklovskaya E, Fazekas de St. Groth B. Pro- and anti-tumour effects of B cells and antibodies in cancer: a comparison of clinical studies and preclinical models. Cancer Immunol Immunother. (2016) 65:885-96. doi: 10.1007/s00262-016-1848-Z

99. Germain C, Gnjatic S, Dieu-Nosjean MC. Tertiary Lymphoid StructureAssociated B Cells are Key Players in Anti-Tumor Immunity. Front Immunol. (2015) 6:67. doi: 10.3389/fimmu.2015.00067

100. Qin Z, Richter G, Schuler T, Ibe S, Cao X, Blankenstein T. B cells inhibit induction of T cell-dependent tumor immunity. Nat Med. (1998) 4:627-30. doi: 10.1038/nm0598-627

101. Barbera-Guillem E, Nelson MB, Barr B, Nyhus JK, May KF, Jr., Feng L, et al. B lymphocyte pathology in human colorectal cancer. Experimental and clinical therapeutic effects of partial B cell depletion. Cancer Immunol Immunother. (2000) 48:541-9. doi: 10.1007/PL00006672

102. Nielsen JS, Sahota RA, Milne K, Kost SE, Nesslinger NJ, Watson $\mathrm{PH}$, et al. $\mathrm{CD} 20+$ tumor-infiltrating lymphocytes have an atypical CD27- memory phenotype and together with CD8 $+\mathrm{T}$ cells promote favorable prognosis in ovarian cancer. Clin Cancer Res. (2012) 18:3281-92. doi: 10.1158/1078-0432.CCR-12-0234

103. Schmidt M, Bohm D, von Torne C, Steiner E, Puhl A, Pilch H, et al. The humoral immune system has a key prognostic impact in node-negative breast cancer. Cancer Res. (2008) 68:5405-13. doi: 10.1158/0008-5472.CAN-07-5206

104. Al-Shibli KI, Donnem T, Al-Saad S, Persson M, Bremnes RM, Busund LT. Prognostic effect of epithelial and stromal lymphocyte infiltration in non-small cell lung cancer. Clin Cancer Res. (2008) 14:5220-7. doi: 10.1158/1078-0432.CCR-08-0133

105. Milne K, Kobel M, Kalloger SE, Barnes RO, Gao D, Gilks CB, et al. Systematic analysis of immune infiltrates in high-grade serous ovarian cancer reveals
CD20, FoxP3 and TIA-1 as positive prognostic factors. PLoS ONE (2009) 4:e6412. doi: 10.1371/journal.pone.0006412

106. Gu-Trantien C, Loi S, Garaud S, Equeter C, Libin M, de Wind A, et al. $\mathrm{CD} 4(+)$ follicular helper $\mathrm{T}$ cell infiltration predicts breast cancer survival. J Clin Invest. (2013) 123:2873-92. doi: 10.1172/JCI67428

107. Ma QY, Huang DY, Zhang HJ, Chen J, Miller W, Chen XF. Function of follicular helper $\mathrm{T}$ cell is impaired and correlates with survival time in non-small cell lung cancer. Int Immunopharmacol. (2016) 41:1-7. doi: 10.1016/j.intimp.2016.10.014

108. Gu-Trantien C, Willard-Gallo K. PD-1(hi)CXCR5(-)CD4(+) TFH cells play defense in cancer and offense in arthritis. Trends Immunol. (2017) 38:875-8. doi: 10.1016/j.it.2017.10.003

109. Gu-Trantien C, Migliori E, Buisseret L, de Wind A, Brohee S, Garaud $\mathrm{S}$, et al. CXCL13-producing TFH cells link immune suppression and adaptive memory in human breast cancer. JCI Insight (2017) 2:91487. doi: 10.1172/jci.insight.91487

110. Huang SC, Wei PC, Hwang-Verslues WW, Kuo WH, Jeng YM, Hu CM, et al. TGF-betal secreted by Tregs in lymph nodes promotes breast cancer malignancy via up-regulation of IL-17RB. EMBO Mol Med. (2017) 9:166080. doi: 10.15252/emmm.201606914

111. Veglia F, Perego M, Gabrilovich D. Myeloid-derived suppressor cells coming of age. Nat Immunol. (2018) 19:108-19. doi: 10.1038/s41590-017-0022-x

112. Wang C, Zhang N, Qi L, Yuan J, Wang K, Wang K, et al. Myeloidderived suppressor cells inhibit $\mathrm{t}$ follicular helper cell immune response in Japanese encephalitis virus infection. J Immunol. (2017) 199:3094-105. doi: 10.4049/jimmunol.1700671

113. Morita R, Schmitt N, Bentebibel SE, Ranganathan R, Bourdery L, Zurawski G, et al. Human blood CXCR5 $(+)$ CD4 $(+) \mathrm{T}$ cells are counterparts of $\mathrm{T}$ follicular cells and contain specific subsets that differentially support antibody secretion. Immunity (2011) 34:108-21. doi: 10.1016/j.immuni.2010.12.012

114. Locci M, Havenar-Daughton C, Landais E, Wu J, Kroenke MA, Arlehamn CL, et al. Human circulating PD-1+CXCR3-CXCR5+ memory Tfh cells are highly functional and correlate with broadly neutralizing HIV antibody responses. Immunity (2013) 39:758-69. doi: 10.1016/j.immuni.2013.08.031

115. Boswell KL, Paris R, Boritz E, Ambrozak D, Yamamoto T, Darko S, et al. Loss of circulating CD4 $\mathrm{T}$ cells with $\mathrm{B}$ cell helper function during chronic HIV infection. PLoS Pathog. (2014) 10:e1003853. doi: 10.1371/journal.ppat.1003853

116. Petrovas C, Koup RA. T follicular helper cells and HIV/SIVspecific antibody responses. Curr Opin HIV AIDS (2014) 9:235-41. doi: 10.1097/COH.0000000000000053

117. Jia Y, Zeng Z, Li Y, Li Z, Jin L, Zhang $Z$, et al. Impaired function of $\mathrm{CD} 4+\mathrm{T}$ follicular helper (Tfh) cells associated with hepatocellular carcinoma progression. PLoS One (2015) 10:e0117458. doi: 10.1371/journal.pone.0117458

118. Zhang H, Yue R, Zhao P, Yu X, Li J, Ma G, et al. Proinflammatory follicular helper $\mathrm{T}$ cells promote immunoglobulin $\mathrm{G}$ secretion, suppress regulatory B cell development, and correlate with worse clinical outcomes in gastric cancer. Tumour Biol. (2017) 39:1010428317705747. doi: 10.1177/1010428317705747

119. Zhu S, Lin J, Qiao G, Wang X, Xu Y. Tim-3 identifies exhausted follicular helper T cells in breast cancer patients. Immunobiology (2016) 221:986-93. doi: 10.1016/j.imbio.2016.04.005

120. Vago L, Antonacci MC, Cristina S, Parravicini C, Lazzarin A, Moroni M, et al. Morphogenesis, evolution and prognostic significance of lymphatic tissue lesions in HIV infection. Appl Pathol. (1989) 7:298-309.

121. Schacker TW, Nguyen PL, Beilman GJ, Wolinsky S, Larson M, Reilly C, et al. Collagen deposition in HIV-1 infected lymphatic tissues and T cell homeostasis. J Clin Invest. (2002) 110:1133-9. doi: 10.1172/JCI0216413

122. Nilsson J, Boasso A, Velilla PA, Zhang R, Vaccari M, Franchini G, et al. HIV-1-driven regulatory T-cell accumulation in lymphoid tissues is associated with disease progression in HIV/AIDS. Blood (2006) 108:3808-17. doi: 10.1182/blood-2006-05-021576

123. Estes JD, Wietgrefe S, Schacker T, Southern P, Beilman G, Reilly C, et al. Simian immunodeficiency virus-induced lymphatic tissue fibrosis is mediated by transforming growth factor beta 1-positive regulatory 
T cells and begins in early infection. J Infect Dis. (2007) 195:551-61. doi: 10.1086/510852

124. Pal S, Schnapp LM. HIV-infected lymphocytes regulate fibronectin synthesis by TGF beta 1 secretion. I Immunol. (2004) 172:3189-95. doi: 10.4049/jimmunol.172.5.3189

125. Border WA, Noble NA. Transforming growth factor beta in tissue fibrosis. $N$ Engl J Med. (1994) 331:1286-92. doi: 10.1056/NEJM199411103311907

126. Zeng M, Smith AJ, Wietgrefe SW, Southern PJ, Schacker TW, Reilly CS, et al. Cumulative mechanisms of lymphoid tissue fibrosis and $\mathrm{T}$ cell depletion in HIV-1 and SIV infections. J Clin Invest. (2011) 121:998-1008. doi: 10.1172/JCI45157

127. Donovan GM, Lythe G. T cell and reticular network co-dependence in HIV infection. J Theor Biol. (2016) 395:211-20. doi: 10.1016/j.jtbi.2016.01.040

128. Bajenoff M, Glaichenhaus N, Germain RN. Fibroblastic reticular cells guide $\mathrm{T}$ lymphocyte entry into and migration within the splenic T cell zone. $J$ Immunol. (2008) 181:3947-54. doi: 10.4049/jimmunol.181.6.3947

129. Chai Q, Onder L, Scandella E, Gil-Cruz C, Perez-Shibayama C, Cupovic J, et al. Maturation of lymph node fibroblastic reticular cells from myofibroblastic precursors is critical for antiviral immunity. Immunity (2013) 38:1013-24. doi: 10.1016/j.immuni.2013.03.012

130. Siegert S, Luther SA. Positive and negative regulation of T cell responses by fibroblastic reticular cells within paracortical regions of lymph nodes. Front Immunol. (2012) 3:285. doi: 10.3389/fimmu.2012.00285

131. Bradley LM, Haynes L, Swain SL. IL-7: maintaining T-cell memory and achieving homeostasis. Trends Immunol. (2005) 26:172-6. doi: 10.1016/j.it.2005.01.004

132. Diaz A, Alos L, Leon A, Mozos A, Caballero M, Martinez A, et al. Factors associated with collagen deposition in lymphoid tissue in long-term treated HIV-infected patients. AIDS (2010) 24:2029-39. doi: 10.1097/QAD.0b013e32833c3268

133. Zeng M, Southern PJ, Reilly CS, Beilman GJ, Chipman JG, Schacker TW, et al. Lymphoid tissue damage in HIV-1 infection depletes naive T cells and limits T cell reconstitution after antiretroviral therapy. PLoS Pathog. (2012) 8:e1002437. doi: 10.1371/journal.ppat.1002437

134. Schacker TW, Nguyen PL, Martinez E, Reilly C, Gatell JM, Horban A, et al. Persistent abnormalities in lymphoid tissues of human immunodeficiency virus-infected patients successfully treated with highly active antiretroviral therapy. J Infect Dis. (2002) 186:1092-7. doi: 10.1086/343802

135. Zaitseva M, Blauvelt A, Lee S, Lapham CK, Klaus-Kovtun V, Mostowski H, et al. Expression and function of CCR5 and CXCR4 on human Langerhans cells and macrophages: implications for HIV primary infection. Nat Med. (1997) 3:1369-75. doi: 10.1038/nm1297-1369

136. Micci L, Alvarez X, Iriele RI, Ortiz AM, Ryan ES, McGary CS, et al. CD4 depletion in SIV-infected macaques results in macrophage and microglia infection with rapid turnover of infected cells. PLoS Pathog. (2014) 10:e1004467. doi: 10.1371/journal.ppat.1004467

137. Sattentau QJ, Stevenson M. Macrophages and HIV-1: an unhealthy constellation. Cell Host Microbe (2016) 19:304-10. doi: 10.1016/j.chom.2016.02.013

138. Musso T, Espinoza-Delgado I, Pulkki K, Gusella GL, Longo DL, Varesio L. IL-2 induces IL-6 production in human monocytes. J Immunol. (1992) 148:795-800.

139. Crotty S. Follicular helper CD4 T cells (TFH). Annu Rev Immunol. (2011) 29:621-63. doi: 10.1146/annurev-immunol-031210-101400

140. Chakrabarti L, Isola P, Cumont MC, Claessens-Maire MA, Hurtrel M, Montagnier L, et al. Early stages of simian immunodeficiency virus infection in lymph nodes. Evidence for high viral load and successive populations of target cells. Am J Pathol. (1994) 144:1226-37.

141. Durudas A, Milush JM, Chen HL, Engram JC, Silvestri G, Sodora DL. Elevated levels of innate immune modulators in lymph nodes and blood are associated with more-rapid disease progression in simian immunodeficiency virus-infected monkeys. J Virol. (2009) 83:12229-40. doi: 10.1128/JVI.01311-09

142. Malleret B, Maneglier B, Karlsson I, Lebon P, Nascimbeni M, Perie L, et al. Primary infection with simian immunodeficiency virus: plasmacytoid dendritic cell homing to lymph nodes, type I interferon, and immune suppression. Blood (2008) 112:4598-608. doi: 10.1182/blood-2008-06-162651
143. Wonderlich ER, Wijewardana V, Liu X, Barratt-Boyes SM. Virusencoded TLR ligands reveal divergent functional responses of mononuclear phagocytes in pathogenic simian immunodeficiency virus infection. $J$ Immunol. (2013) 190:2188-98. doi: 10.4049/jimmunol.1201645

144. Wijewardana V, Bouwer AL, Brown KN, Liu X, Barratt-Boyes SM. Accumulation of functionally immature myeloid dendritic cells in lymph nodes of rhesus macaques with acute pathogenic simian immunodeficiency virus infection. Immunology (2014) 143:146-54. doi: 10.1111/imm.12295

145. Barratt-Boyes SM, Zimmer MI, Harshyne L. Changes in dendritic cell migration and activation during SIV infection suggest a role in initial viral spread and eventual immunosuppression. J Med Primatol. (2002) 31:186-93. doi: 10.1034/j.1600-0684.2002.t01-1-02005.x

146. Wonderlich ER, Wu WC, Normolle DP, Barratt-Boyes SM. Macrophages and myeloid dendritic cells lose $\mathrm{T}$ cell-stimulating function in simian immunodeficiency virus infection associated with diminished IL12 and IFN-alpha production. J Immunol. (2015) 195:3284-92. doi: 10.4049/jimmunol.1500683

147. Presicce P, Shaw JM, Miller CJ, Shacklett BL, Chougnet CA. Myeloid dendritic cells isolated from tissues of SIV-infected Rhesus macaques promote the induction of regulatory $\mathrm{T}$ cells. AIDS (2012) 26:263-73. doi: 10.1097/QAD.0b013e32834ed8df

148. Wonderlich ER, Barratt-Boyes SM. SIV infection of rhesus macaques differentially impacts mononuclear phagocyte responses to virus-derived TLR agonists. J Med Primatol. (2013) 42:247-53. doi: 10.1111/jmp.12064

149. Ferrando-Martinez S, Moysi E, Pegu A, Andrews S, Nganou Makamdop K, Ambrozak D, et al. Accumulation of follicular CD8+ T cells in pathogenic SIV infection. J Clin Invest. (2018) 128:2089-103. doi: 10.1172/JCI96207

150. Petrovas C, Ferrando-Martinez S, Gerner MY, Casazza JP, Pegu A, Deleage C, et al. Follicular CD8 T cells accumulate in HIV infection and can kill infected cells in vitro via bispecific antibodies. Sci Transl Med. (2017) 9:eaag2285. doi: 10.1126/scitranslmed.aag2285

151. Rabin RL, Alston MA, Sircus JC, Knollmann-Ritschel B, Moratz C, Ngo D, et al. CXCR3 is induced early on the pathway of CD4+ T cell differentiation and bridges central and peripheral functions. J Immunol. (2003) 171:281224. doi: 10.4049/jimmunol.171.6.2812

152. Xu W, Joo H, Clayton S, Dullaers M, Herve MC, Blankenship D, et al. Macrophages induce differentiation of plasma cells through CXCL10/IP-10. J Exp Med. (2012) 209:1813-23, S1-2. doi: 10.1084/jem.20112142

153. Groom JR, Luster AD. CXCR3 ligands: redundant, collaborative and antagonistic functions. Immunol Cell Biol. (2011) 89:207-15. doi: 10.1038/icb.2010.158

154. Khan IA, MacLean JA, Lee FS, Casciotti L, DeHaan E, Schwartzman JD, et al. IP-10 is critical for effector $\mathrm{T}$ cell trafficking and host survival in Toxoplasma gondii infection. Immunity (2000) 12:483-94. doi: 10.1016/S1074-7613(00)80200-9

155. Lorenzo-Redondo R, Fryer HR, Bedford T, Kim EY, Archer J, Pond SLK, et al. Persistent HIV-1 replication maintains the tissue reservoir during therapy. Nature (2016) 530:51-6. doi: 10.1038/nature16933

156. Moukambi F, Rodrigues V, Fortier Y, Rabezanahary H, Borde C, Krust B, et al. CD4 T Follicular Helper Cells and HIV Infection: friends or enemies? Front Immunol. (2017) 8:135. doi: 10.3389/fimmu.2017.00135

157. Moukambi F, Rabezanahary H, Rodrigues V, Racine G, Robitaille L, Krust $\mathrm{B}$, et al. Early loss of splenic tfh cells in SIV-infected rhesus macaques. PLoS Pathog. (2015) 11:e1005287. doi: 10.1371/journal.ppat.1005287

158. Aid M, Dupuy FP, Moysi E, Moir S, Haddad EK, Estes JD, et al. Follicular $\mathrm{CD} 4 \mathrm{~T}$ helper cells as a major HIV reservoir compartment: a molecular perspective. Front Immunol. (2018) 9:895. doi: 10.3389/fimmu.2018.00895

159. Thornhill JP, Fidler S, Klenerman P, Frater J, Phetsouphanh C. The role of $\mathrm{CD} 4+\mathrm{T}$ follicular helper cells in HIV infection: from the germinal center to the periphery. Front Immunol. (2017) 8:46. doi: 10.3389/fimmu.2017.00046

160. Lindqvist M, van Lunzen J, Soghoian DZ, Kuhl BD, Ranasinghe S, Kranias G, et al. Expansion of HIV-specific T follicular helper cells in chronic HIV infection. J Clin Invest. (2012) 122:3271-80. doi: 10.1172/JCI64314

161. Onabajo OO, Mattapallil JJ. Expansion or depletion of T follicular helper cells during HIV infection: consequences for B cell responses. Curr HIV Res. (2013) 11:595-600. doi: 10.2174/1570162X12666140225153552

162. Xu H, Wang X, Malam N, Aye PP, Alvarez X, Lackner AA, et al. Persistent simian immunodeficiency virus infection drives differentiation, aberrant 
accumulation, and latent infection of germinal center follicular t helper cells. J Virol. (2016) 90:1578-87. doi: 10.1128/JVI.02471-15

163. Xu H, Wang $\mathrm{X}$, Malam $\mathrm{N}$, Lackner AA, Veazey RS. persistent simian immunodeficiency virus infection causes ultimate depletion of follicular Th cells in AIDS. J Immunol. (2015) 195:4351-7. doi: 10.4049/jimmunol.1501273

164. Jacquelin B, Mayau V, Targat B, Liovat AS, Kunkel D, Petitjean G, et al. Nonpathogenic SIV infection of African green monkeys induces a strong but rapidly controlled type I IFN response. J Clin Invest. (2009) 119:3544-55. doi: $10.1172 /$ JCI 40093

165. Mylvaganam GH, Rios D, Abdelaal HM, Iyer S, Tharp G, Mavigner $\mathrm{M}$, et al. Dynamics of SIV-specific CXCR5+ CD8 T cells during chronic SIV infection. Proc Natl Acad Sci USA. (2017) 114:1976-81. doi: $10.1073 /$ pnas. 1621418114

166. Kwong PD, Mascola JR, Nabel GJ. Broadly neutralizing antibodies and the search for an HIV-1 vaccine: the end of the beginning. Nat Rev Immunol. (2013) 13:693-701. doi: 10.1038/nri3516

167. Cubas RA, Mudd JC, Savoye AL, Perreau M, van Grevenynghe J, Metcalf T, et al. Inadequate T follicular cell help impairs B cell immunity during HIV infection. Nat Med. (2013) 19:494-9. doi: 10.1038/nm.3109

168. Yamamoto T, Lynch RM, Gautam R, Matus-Nicodemos R, Schmidt SD, Boswell KL, et al. Quality and quantity of TFH cells are critical for broad antibody development in SHIVAD8 infection. Sci Transl Med. (2015) 7:298ra120. doi: 10.1126/scitranslmed.aab3964

169. Miles B, Miller SM, Folkvord JM, Kimball A, Chamanian M, Meditz AL, et al. Follicular regulatory $\mathrm{T}$ cells impair follicular $\mathrm{T}$ helper cells in HIV and SIV infection. Nat Commun. (2015) 6:8608. doi: 10.1038/ncomms9608

170. Miles B, Miller SM, Folkvord JM, Levy DN, Rakasz EG, Skinner PJ, et al. Follicular regulatory CD8 T cells impair the germinal center response in SIV and ex vivo HIV infection. PLoS Pathog. (2016) 12:e1005924. doi: 10.1371/journal.ppat.1005924

171. Connick E, Mattila T, Folkvord JM, Schlichtemeier R, Meditz AL, Ray MG, et al. CTL fail to accumulate at sites of HIV-1 replication in lymphoid tissue. J Immunol. (2007) 178:6975-83. doi: 10.4049/jimmunol.178.11.6975

172. Xu L, Pegu A, Rao E, Doria-Rose N, Beninga J, McKee K, et al. Trispecific broadly neutralizing HIV antibodies mediate potent SHIV protection in macaques. Science (2017) 358:85-90. doi: 10.1126/science.aan8630
173. Havenar-Daughton C, Lindqvist M, Heit A, Wu JE, Reiss SM, Kendric K, et al. CXCL13 is a plasma biomarker of germinal center activity. Proc Natl Acad Sci USA. (2016) 113:2702-7. doi: 10.1073/pnas.1520112113

174. Soares EW, Nagai HM, Bredt LC, da Cunha AD, Jr., Andrade RJ, Soares GV. Morbidity after conventional dissection of axillary lymph nodes in breast cancer patients. World J Surg Oncol. (2014) 12:67. doi: 10.1186/1477-7819-12-67

175. van Roozendaal LM, Vane MLG, van Dalen T, van der Hage JA, Strobbe LJA, Boersma LJ, et al. Clinically node negative breast cancer patients undergoing breast conserving therapy, sentinel lymph node procedure versus follow-up: a Dutch randomized controlled multicentre trial (BOOG 2013-08). BMC Cancer (2017) 17:459. doi: 10.1186/s12885-017-3443-x

176. Cyr A, Gao F, Gillanders WE, Aft RL, Eberlein TJ, Margenthaler JA. Disease recurrence in sentinel node-positive breast cancer patients forgoing axillary lymph node dissection. Ann Surg Oncol. (2012) 19:3185-91. doi: 10.1245/s10434-012-2547-4

177. Dirix LY, Takacs I, Jerusalem G, Nikolinakos P, Arkenau HT, Forero-Torres A, et al. Avelumab, an anti-PD-L1 antibody, in patients with locally advanced or metastatic breast cancer: a phase 1b JAVELIN Solid Tumor study. Breast Cancer Res Treat. (2018) 167:671-86. doi: 10.1007/s10549-017-4 537-5

178. Nanda R, Chow LQ, Dees EC, Berger R, Gupta S, Geva R, et al. Pembrolizumab in patients with advanced triple-negative breast cancer: phase Ib KEYNOTE-012 study. J Clin Oncol. (2016) 34:2460-7. doi: 10.1200/JCO.2015.64.8931

Conflict of Interest Statement: The authors declare that the research was conducted in the absence of any commercial or financial relationships that could be construed as a potential conflict of interest.

Copyright (C) 2018 Poultsidi, Dimopoulos, He, Chavakis, Saloustros, Lee and Petrovas. This is an open-access article distributed under the terms of the Creative Commons Attribution License (CC BY). The use, distribution or reproduction in other forums is permitted, provided the original author(s) and the copyright owner(s) are credited and that the original publication in this journal is cited, in accordance with accepted academic practice. No use, distribution or reproduction is permitted which does not comply with these terms. 